\title{
Study of the in vitro release profile of sesquiterpenes from a vaginal cream containing Copaifera ducke Dwyer (F abaceae) oleoresin
}

\author{
Helison Oliveira Carvalho, Clarissa Silva Lima, Anderson Almeida Sanches, Jocivania Oliveira da Silva, \\ Caio Pinho Fernandes, Jose Carlos Tavares Carvalho* \\ Laboratório de Pesquisa em Fármacos, Departamento de Ciências Biológicas e da Saúde, Colegiado de Ciências Farmacêuticas, Universidade Federal do \\ Amapá, Rod. Juscelino Kubitschek, Km 02, CEP 68902-280, Macapá, Amapá, Brasil.
}

\begin{tabular}{|c|c|}
\hline ARTICLE INFO & ABSTRACT \\
\hline Article history: & \multirow{6}{*}{$\begin{array}{l}\text { Copaiba trees and their oleoresin is an important natural product used as an anti-inflammatory and antimicrobial } \\
\text { drug, in particular for gynecological infections. The in vitro release profile of sesquiterpenes in a vaginal cream } \\
\text { containing copaiba (CVC - copaiba vaginal cream) oleoresin in buffered solutions at different pHs was evaluated } \\
\text { in the present study. The dissolution test revealed that trans-caryophyllene (TC) was constantly released until the } \\
\text { final test time. The maximum peaks were found at a concentration of } 478.79 \mathrm{~nL} / \mathrm{mL} \text { for the buffer at } \mathrm{pH} 5 \text { and at } \\
\text { a concentration of } 475.99 \mathrm{~nL} / \mathrm{mL} \text { for the buffer at } \mathrm{pH} 6 \text {, with a percentage release of } 50.52 \% \text { and } 50.21 \% \text {, } \\
\text { respectively. Likewise, the caryophyllene oxide }(\mathrm{CO}) \text { was released into the buffers at pHs } 5 \text { and } 6 \text {, with } \\
\text { maximum release peaks at } 60 \text { minutes at a percentage of } 31.8 \% \text { and } 33.5 \% \text { corresponding to concentrations of } \\
2.779 \text { and } 2.925 \mu \mathrm{g} / \mathrm{mL} \text {, respectively. The release and dissolution profiles of the sesquiterpene compounds } \\
\text { indicated that a pH of } 5-6 \text { in the dissolution media is adequate for release of these markers of antimicrobial } \\
\text { activity in Copaifera duckei Dwyer. Therefore, these conditions possibly favor the therapeutic action of CVC. }\end{array}$} \\
\hline Received on: 29/10/2014 & \\
\hline Revised on: 28/11/2014 & \\
\hline Accepted on: 19/12/2014 & \\
\hline Available online: $27 / 04 / 2015$ & \\
\hline $\begin{array}{l}\text { Key words: } \\
\text { Copaifera, oleoresin, } \\
\text { sesquiterpenes, dissolution. }\end{array}$ & \\
\hline
\end{tabular}

\section{INTRODUCTION}

Copaiba trees belong to the genus Copaifera L., family Fabaceae, subfamily Caesalpinioideae. These plants are slowgrowing trees, measuring $25-40 \mathrm{~m}$ in height, featuring a rough and dark trunk 0.4-4 $\mathrm{m}$ in diameter and living up to 400 years of age (Silvia et al., 2008). Copaiba trees are native to the tropical regions of Latin America and Western Africa and can be found in the Americas in the region spanning from Mexico up to the north of Argentina (Veiga-Júnior and Pinto, 2002). The genus Copaifera comprises 72 species, 16 of which can only be found in Brazil (Dwyer, 1951); the species Copaifera duckei Dwyer is prominent among them. The copaiba oleoresin is an important natural product used in folk medicine as an anti-inflammatory, anti-septic, and wound healing substance, especially for the upper

\footnotetext{
* Corresponding Author

Laboratório de Pesquisa em Fármacos, Departamento de Ciências Biológicas e da Saúde, Colegiado de Ciências Farmacêuticas, Universidade Federal do Amapá, Rod. Juscelino Kubitschek, Km 02, CEP 68902-280, Macapá, Amapá, Brasil..Email: farmacos@unifap.br
}

airways and urinary tract (Basile, 1988; Carvalho and Cascon, 2003; Carvalho, 2005). Some authors report that the oleoresin is a detoxification product of the plant organism, functioning as a defense mechanism against animals, fungi, and bacteria (Alencar, 1982; Macedo and Langenheim, 1989). Various pharmacological studies of the copaiba oleoresin have already been described in the literature, including the compound's antimicrobial and antibacterial (Opdyke, 1976; Miranda et al., 2000; Tincusi et al., 2002), analgesic (Carvalho et al., 2005), anti-inflammatory (Fernandes et al., 1992; Carvalho et al, 2005), wound healing (Brito, 1999), gastroprotective (Paiva et al., 1998), and antitumoral (Ohsaki et al., 1994; Lima et al., 2003) activities. Antimicrobial studies have revealed that the oleoresins of various copaiba tree species exhibit this activity, which may be related to the terpenic compounds present in the oleoresin (Muroi and Kobo, 1993; Sharfin, 2002; Santos et al., 2008). Studies conducted by Santos et al. (2008) using electron microscopy corroborate this hypothesis because Staphylococcus aureus strains underwent changes, such as the loss of their cell walls and the release of cytoplasmic compounds, after treatment with oleoresin. 
Lima et al. (2011) demonstrated that a vaginal cream containing $2.5 \%$ copaiba oleoresin is safe during gestation in female rats (Rattus norvegicus) of the Wistar strain.

The normal physiological $\mathrm{pH}$ in the vagina varies between 3.8 and 4.2. These acidic values result from the secretion of organic acids by the vaginal epithelial cells and from the production of lactic acid from glycogen by bacilli and lactobacilli constituting the normal vaginal microbiota (Jarmy-Di Bella et al., 2009).

Among the most frequent vaginal infectious processes, bacterial vaginosis, vulvovaginitis, and trichomoniasis are the most prominent (Sobel, 1990). Several of these polymicrobial infections promote changes in the microbiota, significantly reducing the number of lactobacilli and increasing the $\mathrm{pH}$ to values above 3.5, which favors the growth of bacteria such as Gardnerella vaginalis, Mycoplasma hominis, Mobiluscus sp., and Bacteroides (Murta et al., 2000; Adad et al., 2001; Marrazzo, 2003).

Extremely acidic vaginal $\mathrm{pHs}$ are commonly found in fungal infections, which are generally caused by Candida sp. Conversely, alkaline vaginal $\mathrm{pH}$ values are mostly associated with Trichomonas vaginalis infections and with bacterial vaginosis caused by Gardnerella vaginalis. Depending on factors such as age, vaginal microbiota, and menstrual period, the vaginal $\mathrm{pH}$ can range between 3.8 and 7 (Jarmy-Di Bella et al., 2009).

The aim of the present study was to evaluate the in vitro release profile of sesquiterpenes from a vaginal cream containing $2.5 \%$ copaiba oleoresin in buffered solutions at $\mathrm{pHs}$ ranging from 3 to 6 , which are the threshold $\mathrm{pH}$ values usually found in vaginal fluids exhibiting a modified microbiota.

\section{MATERIALS AND METHODS}

Obtainment of the oleoresin and copaiba vaginal cream (CVC)

The oleoresin used for analysis and pharmaceutical development was obtained from the company Beraca Ltd., located at Ananindeua, in Pará State, Brazil. According to the company's report, the oleoresin belongs to the species Copaifera duckei Dwyer.

The CVC and the base cream were obtained at a concentration of $2.5 \%$, supplied in polyethylene bottles, from the Pharmaceutical Laboratory Almeida Prado, Ltd., in the city and state of São Paulo, Brazil.

\section{CVC dissolution assay}

Buffer solutions were prepared at $\mathrm{pH} 3,4,5$, and 6, using hydrochloric acid $(\mathrm{HCl})$ and $0.2 \mathrm{M}$ sodium hydroxide $(\mathrm{NaOH})$ in distilled water (Farmacopeia Brasileira, 2010). One hundred milliliters of each buffer solution was placed in dissolution tanks of the dissolution test system model 299 (Nova Ética, Ltd. São Paulo, Brazil) with the paddle apparatus, a stirring rate of 40 RPM, and a controlled temperature of $37 \pm 1^{\circ} \mathrm{C}$. Exactly $5 \mathrm{~g}$ of CVC at a concentration of $2.5 \%$ oleoresin was used for the release profile analysis. The dissolution and release profiles were obtained from the quantification of the levels of phytochemical sesquiterpenoid compounds, caryophyllene oxide $(\mathrm{CO})\left(\mathrm{C}_{15} \mathrm{H}_{24} \mathrm{O}\right)$, and transcaryophyllene (TC) $\left(\mathrm{C}_{15} \mathrm{H}_{24}\right)$ released from the CVC into the solutions in the tanks at the timepoints of 10,30,60, 90, 120, and 150 minutes.

One-milliliter aliquots were collected at the given time points for the extraction of the non-polar fraction by liquid-liquid partitioning with $1 \mathrm{~mL}$ of hexane. After separation, the hexane fraction was analyzed by gas chromatography.

\section{Analysis of the samples obtained in the dissolution test}

The analysis of the samples was conducted by gas chromatography using the method described by Lima et al. (2011). The sesquiterpene contents were calculated from the equation of the standard curve obtained using CO (Sigma-Aldrich, lot $128 \mathrm{H} 3429)$ at concentrations of $5,10,20,40$, and $80 \mu \mathrm{g} / \mathrm{mL}$ and TC (Sigma-Aldrich, lot BCBJ3860V) at concentrations of 250, $500,1,000,2,000$, and $4,000 \mathrm{~nL} / \mathrm{mL}$, using the average of three measurements (Figures 1, 2, 3, 4, 5, 6 e 7).

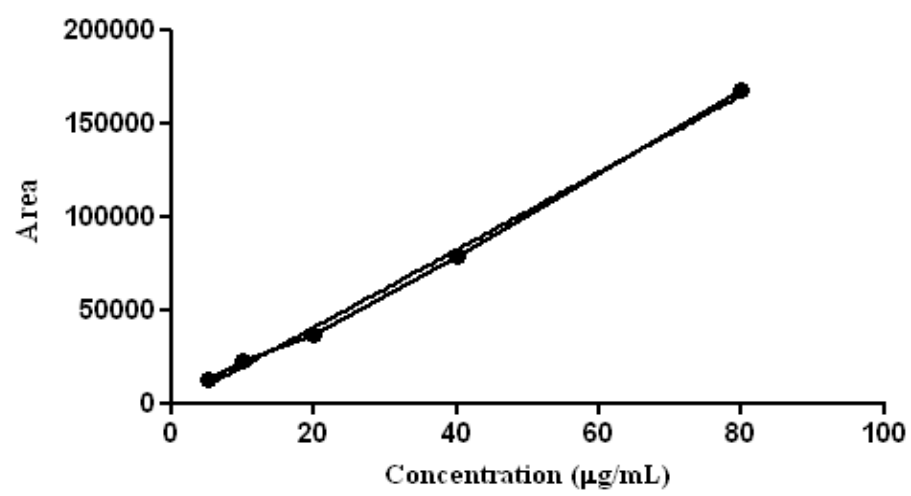

Fig. 1: Standard CO curve obtained using GC-FID at concentrations of 5 to 80 $\mu \mathrm{g} / \mathrm{mL}$, with the equation $\mathrm{y}=1862 \mathrm{x}-4.208$ and the coefficient of determination $\mathrm{R}^{2}=0.9969$.

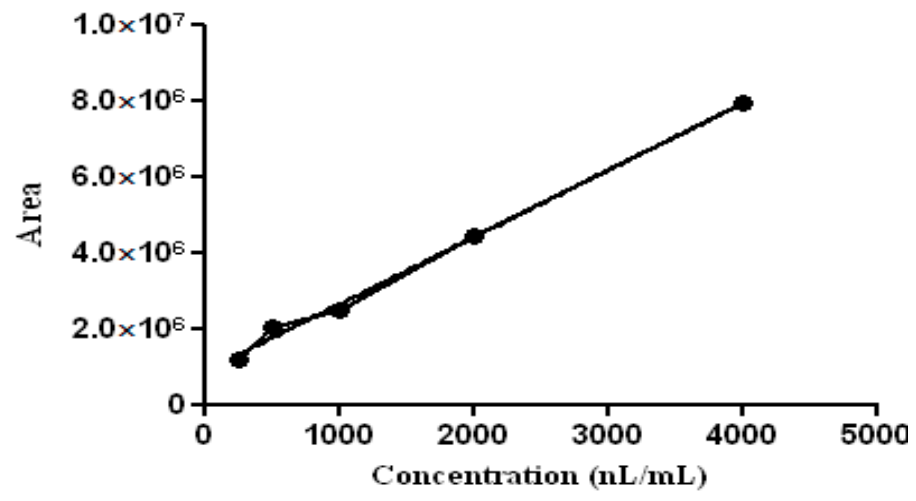

Fig. 2: Standard TC curve obtained using GC-FID at concentrations of 250 to $4,000 \mathrm{~nL} / \mathrm{mL}$, with the equation $\mathrm{y}=1555 \mathrm{x}-821.1$ and the coefficient of determination $R^{2}=0.9959$. 

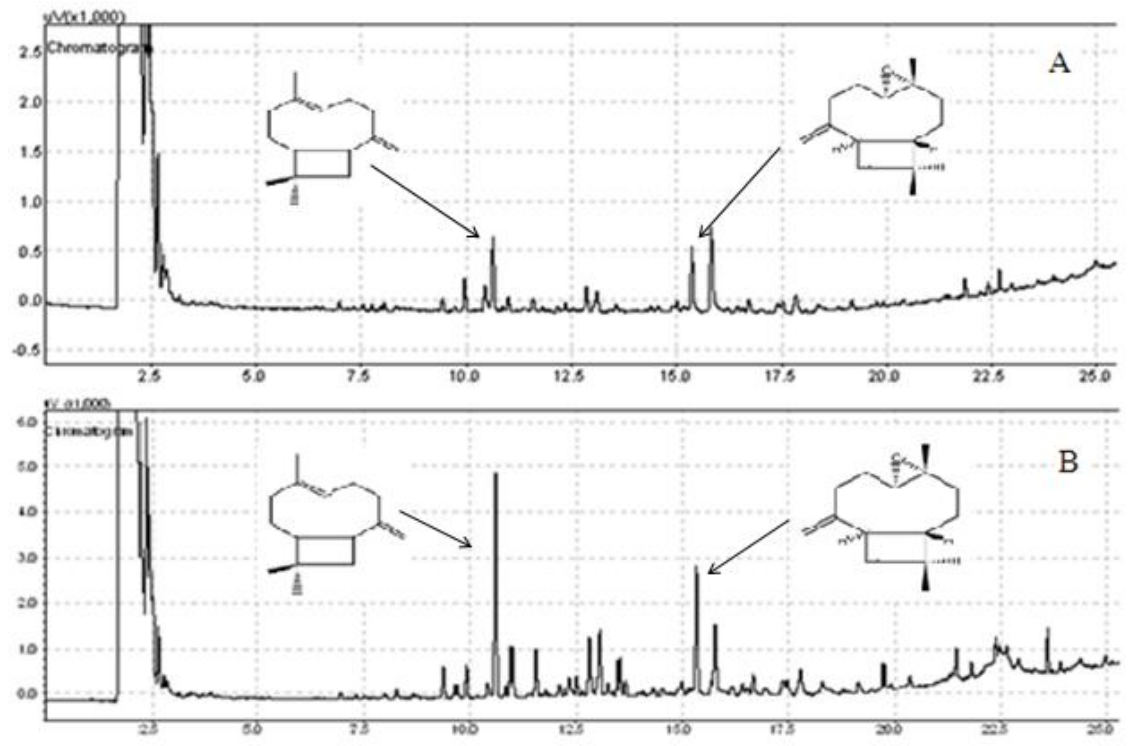

Fig. 3: Comparison of chromatographic profiles of CVC (A) and C. duckei oleoresin (B) indicating the quantified sesquiterpenes (CO and TC), obtained by GCMS with the injection of $1 \mu \mathrm{L}$ in the split mode (20:1 split ratio).

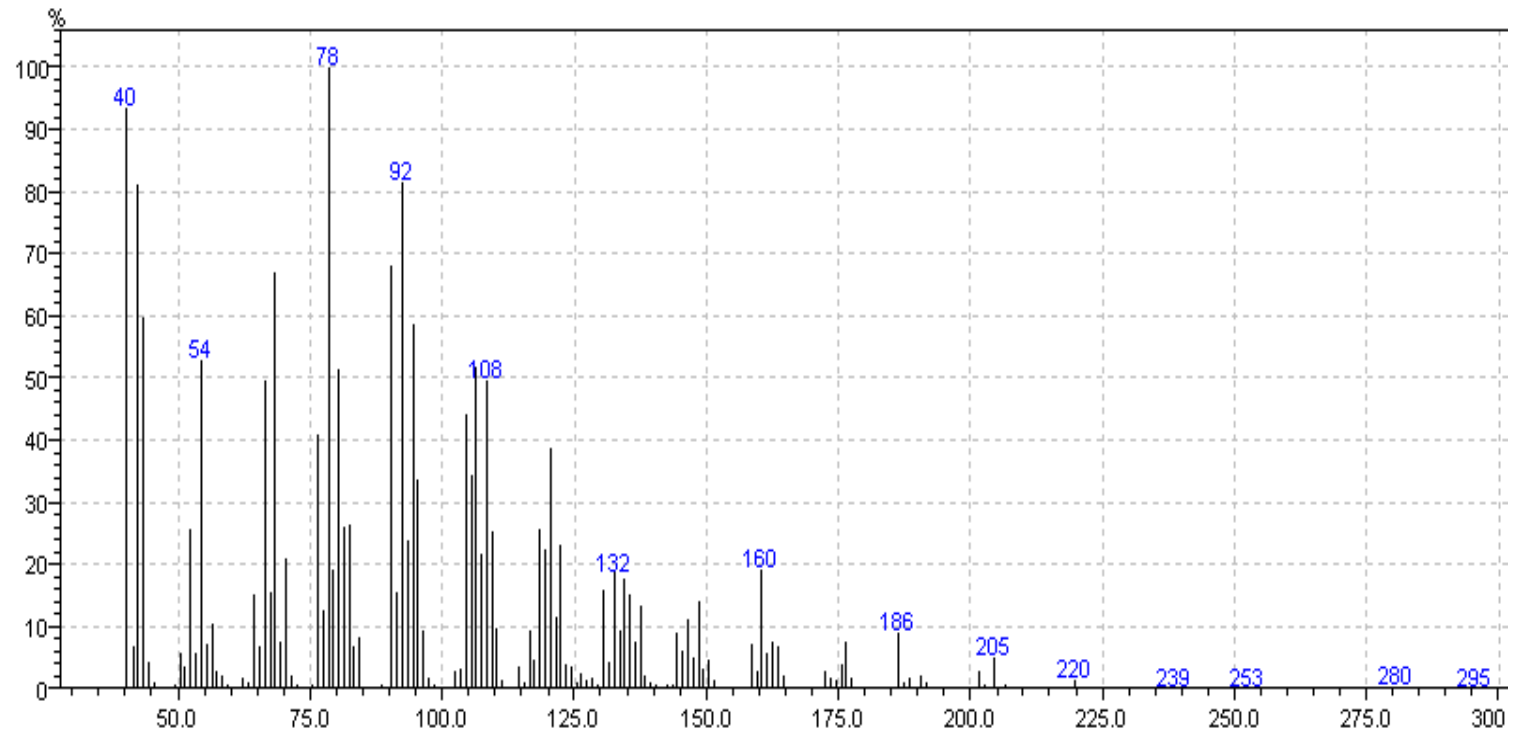

Fig. 4: Fragmentation profile of the sesquiterpene standard $\mathrm{CO}\left(\mathrm{C}_{15} \mathrm{H}_{24} \mathrm{O}, \mathrm{M} 220\right)$, obtained by GC-MS (QP2010SE).

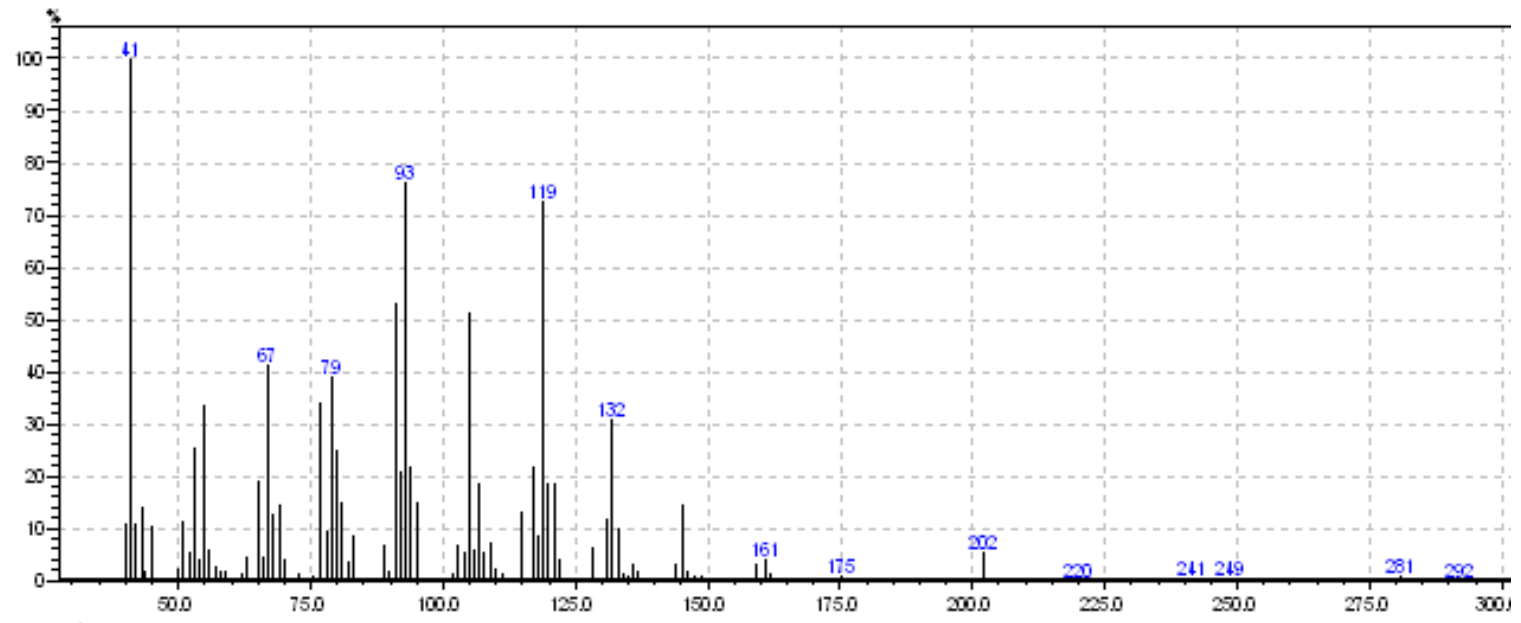

Fig. 5: Fragmentation profile of the sesquiterpene $\mathrm{CO}\left(\mathrm{C}_{15} \mathrm{H}_{24} \mathrm{O}, \mathrm{M} 220\right)$ of the copaiba oil (Copaifera duckei Dwyer), obtained by GC-MS (QP2010SE). 


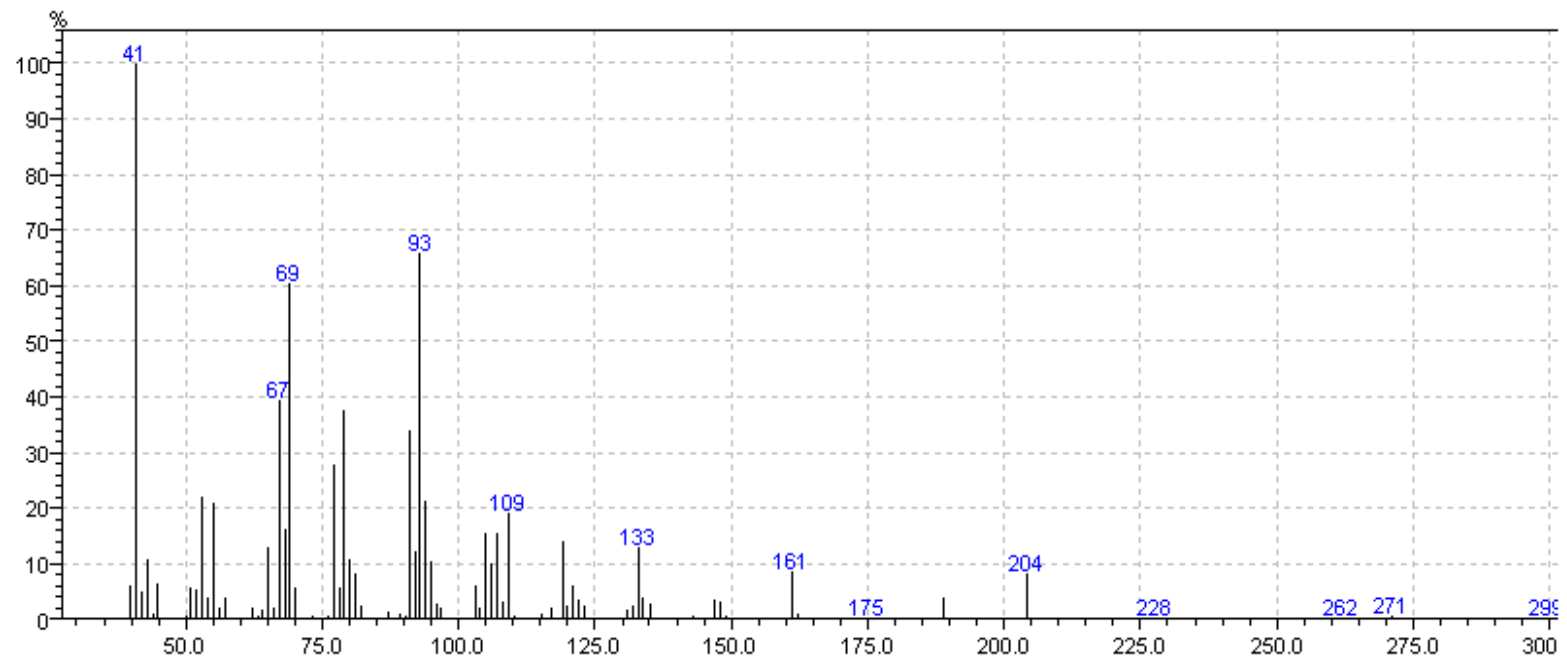

Fig. 6: Fragmentation profile of the sesquiterpene standard TC $\left(\mathrm{C}_{15} \mathrm{H}_{24}, \mathrm{M} 204\right)$, obtained by GC-MS (QP2010SE).

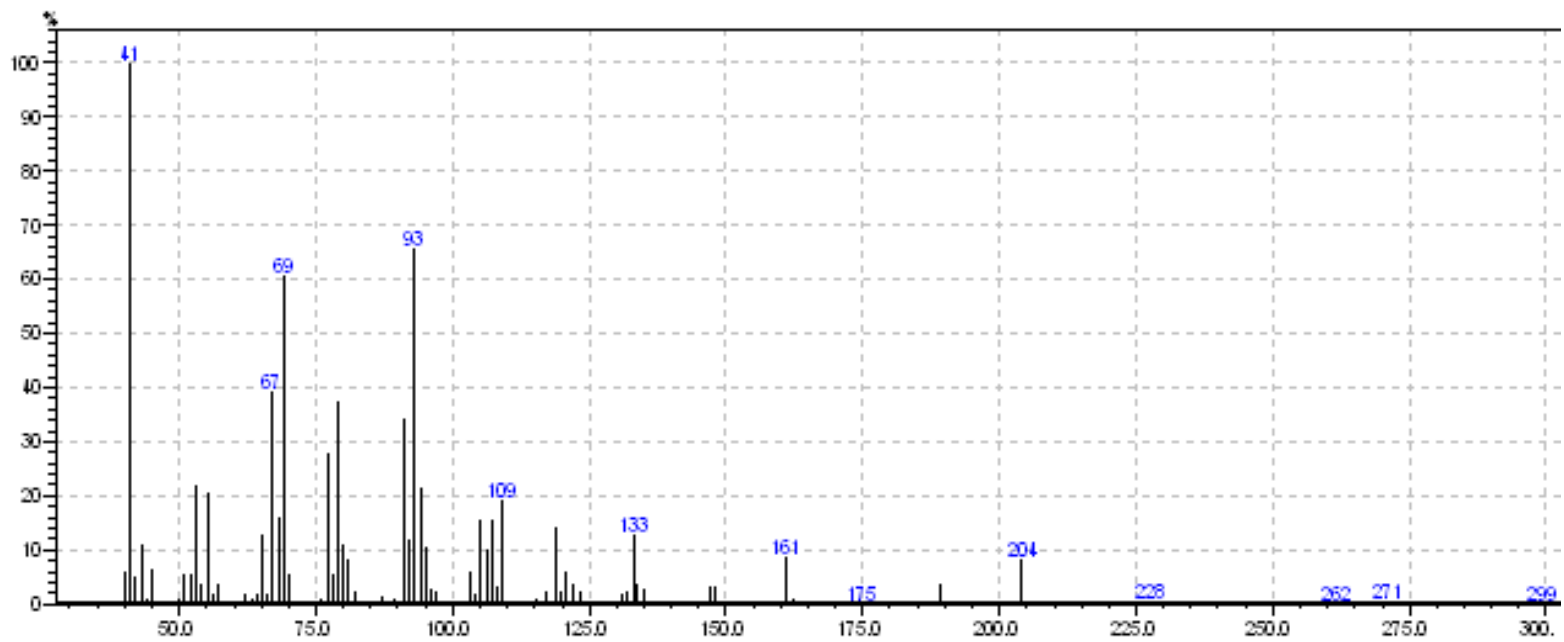

Fig. 7: Fragmentation profile of the sesquiterpene $\mathrm{TC}\left(\mathrm{C}_{15} \mathrm{H}_{24}, \mathrm{M} 204\right)$ of copaiba oil (Copaifera duckei Dwyer), obtained by GC-MS (QP2010SE).
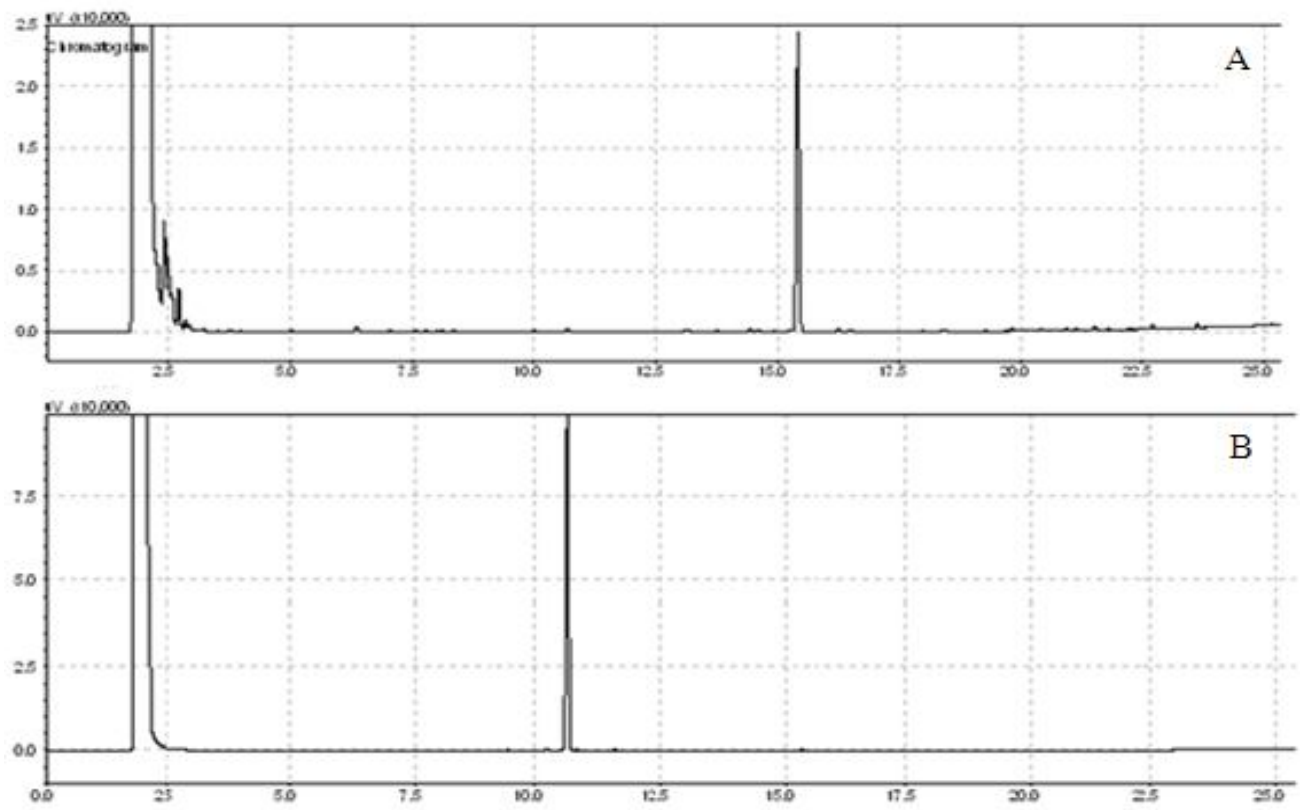

Fig. 8: Comparison of chromatographic profiles of standard compounds, where (A) CO and (B) TC were obtained by GC-MS with retention times of 15.38 and 10.64 minutes, respectively. 
A gas chromatograph (Shimadzu GC-plus 2010) with a flame ionization detector (GC-FID) was used with a capillary column Rtx-1 consisting of polydimethylsiloxane $(30 \mathrm{~m} \times 0.25$ $\mathrm{mm}$ ID $\times 0.25 \mu \mathrm{m})$ as the stationary phase. Helium was used as the carrier gas at a flow of $1.5 \mathrm{~mL} / \mathrm{minute}$. The oven temperature was programmed as follows: the temperature was maintained at $120^{\circ} \mathrm{C}$ for 2 minutes, then increased at a rate of $3^{\circ} \mathrm{C} /$ minute up to $160^{\circ} \mathrm{C}$, which was maintained for another 2 minutes, and finally increased at a rate of $8^{\circ} \mathrm{C} /$ minute up to a final temperature of $290^{\circ} \mathrm{C}$, which was maintained for 5 minutes. The injector and detector temperatures were maintained at $270^{\circ} \mathrm{C}$ and $290^{\circ} \mathrm{C}$, respectively. A volume of $1.0 \mu \mathrm{L}$ (hexane fraction) was injected using a split ratio of 20:1. A gas chromatograph coupled to a mass spectrometer (QP2010SE) (GC-MS) was used under similar conditions to the GC-FID, operated in the Scan 40-400 ( $\mathrm{m} / \mathrm{z})$ mode, with an electron impact of $-70 \mathrm{eV}$.

\section{Statistical analysis}

The results from each analysis were statistically analyzed using ANOVA followed by a linear regression test. The dissolution profiles were compared using the Student-NewmanKeuls test, and results with p values less than 0.05 were considered significant. The GraphPad Instat ${ }^{\circledR}$ and Prism ${ }^{\circledR}$ version 5.03 software were used.

\section{RESULTS AND DISCUSSION}

The analysis of the copaiba oleoresin by gas chromatography with a flame ionization detector was undertaken using external standards with a CO content of $7.746 \pm 0.022$ $\mu \mathrm{g} / \mathrm{mg}(\mathrm{n}=3)$, which corresponded to a percentage area of $2.68 \pm$ $0.19 \%$, and using a TC content of $946.67 \pm 14.34 \mathrm{~nL} / \mathrm{mL}(\mathrm{n}=3)$, with an area of $9.34 \pm 0.34 \%$. The retention times of both compounds were 15.38 and 10.64 minutes, respectively (Fig. 8). The GC-MS analysis of non-esterified $C$. duckei oleoresin samples undertaken by Lima (2011), using the same chromatographic conditions with the only exception of the chromatographic column, also revealed the presence of $\mathrm{CO}$ and $\mathrm{TC}$ in the species. However, the retention times were 9.39 and 6.01 minutes. TC and its corresponding oxide are sesquiterpenes usually found in the various copaiba species and in many essential oils of a number of species from different botanic families. These two compounds may actually represent the major part of sesquiterpenes present in the species as these compounds yield numerous pharmacological effects, including anti-inflammatory (Shimizu, 1990), antitumoral (Zheng et al., 1992), spasmolytic (Duke, 1992), and antimicrobial activities that protect the plant by inhibiting fungal and bacterial proliferation (Kang et al., 1992, Veiga-junior, 2002). The in vitro dissolution test is critical for assessing the drug performance and for correlation with in vivo results (Amidon et al., 1995). The active principle must be completely solubilized, with total disintegration of its carrier, being constituted solely by small particles capable of making contact with the biological membranes so that the drug can be absorbed (Ansel et al., 2000). Thus, controlling the experimental conditions is crucial to guaranteeing the reliability and reproducibility of the test. The CVC dissolution test using $\mathrm{TC}$ as the marker displayed a progressive release until the final dissolution timepoint, with maximum concentration peaks of $478.79 \mathrm{~nL} / \mathrm{mL}$ for the buffer at $\mathrm{pH} 5$ and $475.99 \mathrm{~nL} / \mathrm{mL}$ for the buffer at $\mathrm{pH} 6$ and with a percentage release of $50.52 \%$ and $50.21 \%$, respectively. The dissolution media at $\mathrm{pHs} 5$ and 6 exhibited a significant difference relative to the other dissolution media (Fig. 9). For the $\mathrm{CO}$ marker, the release was more efficient at pHs 5 and 6 , with maximum peaks at 60 minutes and a higher statistical significance compared with the other dissolution media. The CO-release percentages were $31.8 \%$ and $33.5 \%$, corresponding to concentrations of $2.779 \mu \mathrm{g} / \mathrm{mL}$ and $2.925 \mu \mathrm{g} / \mathrm{mL}$, respectively. Poor dissolution occurred in the buffers at pHs 3 and 4. A maximum $\mathrm{CO}$ release value of $2.059 \mu \mathrm{g} / \mathrm{mL}$ in 90 minutes was observed at $\mathrm{pH} 3$ and was higher than the value obtained in the buffer at $\mathrm{pH} 4$, which was $1.968 \mu \mathrm{g} / \mathrm{mL}$ in 60 minutes, equivalent to a percentage of $22.5 \%$. The buffer solutions at $\mathrm{pHs} 5$ and 6 effectively led to $\mathrm{CVC}$ dissolution. Although a higher $\mathrm{CO}$ release was obtained at $\mathrm{pH} 6$, a better profile was observed at $\mathrm{pH}$ 5 , exhibiting a gradual and uniform increase of the release during the course of the dissolution, up to 120 minutes (Fig. 10).

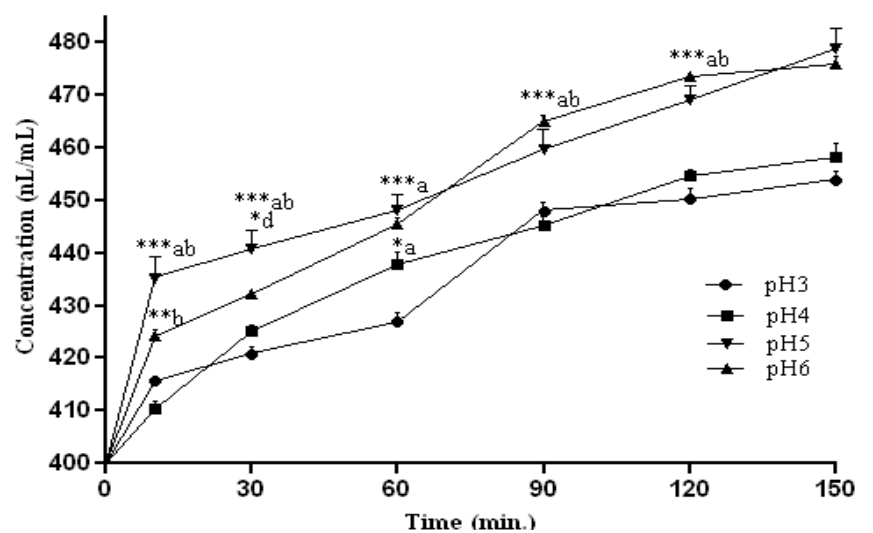

Fig. 9: Dissolution and release profiles of CVC TC in different buffer solutions. Student-Newman-Keuls test, where ${ }^{*} \mathrm{p}<0.05$, **p $<0.01$, and $* * * \mathrm{p}$ $<0.001$; (a) comparison with $\mathrm{pH}=3$, (b) comparison with $\mathrm{pH}=4$, and (d) comparison with $\mathrm{pH}=6$.

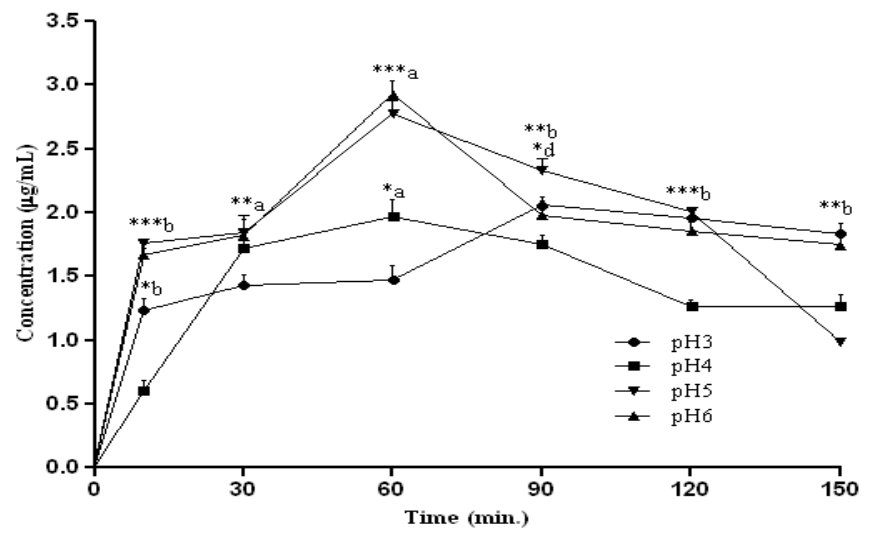

Fig. 10: Dissolution and release profiles of CVC CO in different buffer solutions. Student-Newman-Keuls test, where $* \mathrm{p}<0.05$, $* * p<0.01$, and $* * * p$ $<0.001$; (a) comparison with $\mathrm{pH}=3$, (b) comparison with $\mathrm{pH}=4$, and (d) comparison with $\mathrm{pH}=6$ 


\section{CONCLUSION}

In conclusion, the CVC dissolution was tested in different buffered solutions that simulated the vaginal $\mathrm{pH}$. The results demonstrated that better release of the phytochemical markers was observed at pHs 5 and 6. Taking into consideration the CVC dissolution and release profiles, this phytotherapeutic product is expected to exhibit greater therapeutic action at vaginal $\mathrm{pH}$ conditions ranging from 5 to 6 .

\section{ACKNOWLEDGMENTS}

The editors acknowledge financial support from $\mathrm{CNPq}$ process number 550897/2007-0 edital BIOINOVA and 306676/2010-9, and PPSUS-SETEC-CNPq (CNPq/DPT/CGSAU) RG. Nr. 48/2006/MCT/CNPq/SETEC.

\section{REFERENCES}

Adad SJ, de Lima RV, Sawan ZT, Silva ML, de Souza MA, Saldanha JC, Falco VA, da Cunha AH, Murta EF. Frequency of Trichomonas vaginalis, Candida sp. and Gardnerella vaginalis in cervical-vaginal smears in four different decades. Sao Paulo Med J, 2001; 119: 200-205.

Alencar JC. Estudos Silviculturais de uma população natural de Copaifera multijuga Hayne (Leguminosae), na Amazonia Central. Acta Amaz, 1982; 1: 75-89.

Amidon GL, Lennernãs H, Shah VP, Crison JR. A theoretical basis for a biopharmaceutic drug classification: the correlation of in vitro drug product dissolution and in vivo bioavailability. Pharm Res, 1995; 12:413-420.

Ansel HC, Popovick NC, Allen JLV, 2007. Formas farmacêuticas e sistemas de liberação de fármacos. São Paulo, Brasil: Artmed Editora S.A.

Basile AC. Anti-inflammatory activity of oleoresin from Brazilian Copaifera. J Ethnopharmacol, 1988; 22:100-101.

Brito NMB. Aspectos microscópicos da cicatrização de feridas abertas tratadas com óleo de copaída em ratos. Rev. Paraense Med, 1999; 13:12-17.

Carvalho JCT. Topical anti-inflammatory and analgesic activities of Copaifera duckei Dwyer. Phytoth Res, 2005; 19:946-950.

Carvalho JCT, Cascon V. 2003. Fitoterápicos: Nova opção farmacêutica de anti-inflamatórios (Aspectos químicos, farmacológicos e aplicações terapêuticas). São Paulo, Brasil: Editora Robe.

Duke JA. 1992. Handbook of biologically active phytochemicals and their activities. London, England: CRC Press, Boca Raton.

Dwyer JD. The Central American, West Indian and South American species of Copaifera (Caesalpiniaceae). Brittonia, 1951;17:143172

Farmacopeia Brasileira. 2010. Métodos aplicados a medicamentos e físicos e químicos. Farmacopeia Brasileira. Brasilia, Brasil: Agência Nacional de Vigilância Sanitária.

Fernandes RM, Pereira NA, Paulo GL. Anti-inflammatory activity of copaiba balsam (Copaifera cearensis Huber). Rev Bras Farm, 1992; 73:53-56.

Jarmy-Di Bella ZIK, Araujo MP, Martins KDF, Zucchi EVM, Girão MJBC, Sartori MGF. The use of liquid soap for female intimate care. Femina, 2009; 37:229-234.

Kang R, Helms R, Stout MJ, Jaber H, Nakatsu T. Vietnamese culinary herbs in the United States. J Agric Food Chem, 1992; 40:23282332 .

Lima CS. 2011. Aproveitamento de recursos naturais: Estudo da performance reprodutiva com aplicação do óleo de copaíba (Copaifera duckei Dwyer) veiculado em creme vaginal. Master's dissertation in
Biodiversity, Amapá, Brasil: Programa de Pós-graduação em Biodiversidade Tropical, Universidade Federal do Amapá.

Lima CS, de Medeiros BJL, Favacho HAS, dos Santos KC, de Oliveira BR, Taglialegna JC, da Costa EVM, de Campos KJ, Carvalho JCT. Pre-clinical validation of a vaginal cream containing copaiba oil (reproductive toxicology study). Phytomedicine, 2011; 18:1013-1023.

Lima SR, Junior VF, Christo HB, Pinto AC, Fernandes PD. In vivo and in vitro studies on the anticancer activity of Copaifera multijuga Hayne and its fractions. Phytother Res, 2003; 17:1048-1053.

Macedo CA, Langenheim JH. Intrad inter-plant sesquiterpene variability in Copaifera langsdorfii: elation microlepdopteran herbivory. Biochem System Ecol, 1989; 17:551-557.

Marrazzo JM. Bacterial vaginosis. Curr. Treat Opt Infect Dis, $2003 ; 5: 63-68$

Miranda RCM, Wanderley TKV, Moura W, Araújo JM. 2000. Antimicrobial activity of copaiba oil (Copaiba spp.) from various sources in: Proceedings of the $16^{\text {th }}$ Symposium on Medicinal Plants of Brazil, Recife, Brasil.

Muroi H, Kubo I. Combination effects of antibacterial compounds in green tea flavor against Streptococcus mutans. J Agric Food Chem, 1993; 41:1102-1105.

Murta EFC, Souza, MAH, Araujo Junior E, Adad SJ. Incidence of Gardnerella vaginalis, Candida sp. and human papilloma virus in cytological smears. Sao Paulo Med J, 2000; 118:105-108.

Ohsaki A, Yan LT, Ito S, Edatsugi H, Iwata D, Komodo Y. The isolation and in vivo potent antitumor activity of a clerodane deterpenoid from the oleoresin of the Brazilian medicinal plant, Copaifera langsdorfii. Desf. Bio Med Chem Letters. 1994; 4:2889-2892.

Opdyke DL. Inhibition of sensitization reactions induced by certain aldehydes. Food Cosmet. Toxicol, 1976; 14:197-198.

Paiva LA, Rao VS, Gramosa NV, Silveira ER. Gastroprotective effect of Copaifera langsdorfii oleoresin on experimental gastric ulcer models in rats. J Ethnopharmacol, 1998; 62:73-78.

Santos AO, Ueda-Nakamura T, Dias Filho BP, Veiga Junior VF, Pinto AC, Nakamura CV. Antimicrobial activity of Brazilian Copaiba oils obtained from different species of the Copaifera genus. Mem. Inst. Osvaldo Cruz, 2008; 103:277-283.

Sharfin PM. Antibacterial activity of the essential oil from Aristolochia indica. Fitoterapia, 2002; 73:439-441.

Shimizu M. Quantity estimation of some contaminants in commonly used medicinal plants. Chem. Pharm Bull, 1990; 38:2283-2287.

Sobel JD. Vaginal infections in adult women. Med Clin N Amer, 1990; 74:1573-1602.

Silvia RC, Pereira JF, Lima HC. O gênero Copaifera (Leguminosae Cesalpinoideae) na Amazônia Brasileira. Rodriguésia, 2008; 59:455-476.

Tincusi BM, Jimenez IA, Bazzocchi IL, Moujir LM, Mamani ZA, Barroso JP, Ravelo AG, Hernandez BV. Antimicrobial terpenoids from the oleoresin of the Peruvian medicinal plant Copaifera paupera. Plant Med, 2002; 68:808-812.

Veiga Junior VF, Pinto AC. O gênero Copaifera L [The genus Copaifera L.]. Quím Nov, 2002; 25:272-286.

Zheng GQ, Kenney PM, Lam LKT. Efficacy, safety, quality control, marketing and regulatory guidelines for herbal medicines. Nat Prod, 1992; 55:999-1003.

\section{How to cite this article:}

Carvalho H. O., Lima C. S., Sanches A. A., Oliveira da Silva J., Fernandes C. P., Tavares Carvalho J. C. Study of the in vitro release profile of sesquiterpenes from a vaginal cream containing Copaifera duckei Dwyer (Fabaceae) oleoresin. J App Pharm Sci, 2015; 5 (04): 001-006. 